\title{
FORMULASI SEDIAAN MIKROEMULSI MENGANDUNG MINYAK BIJI JINTAN HITAM (Nigella sativa L.) DAN MINYAK ZAITUN (Olea europaea L.)
}

\author{
${ }^{1}$ Zainab Zahira Azzahra, ${ }^{2}$ Sani Ega Priani, ${ }^{3}$ Amila Gadri \\ ${ }^{1,2,3}$ Program Studi Farmasi, Fakultas Matematika dan Ilmu Pengetahuan Alam, Universitas Islam Bandung, \\ J1. Tamansari No.1 Bandung 40116 \\ email:12z.azzahra79@gmail.com, ${ }^{2}$ egapriani@gmail.com, ${ }^{3}$ amilagadriapt@gmail.com
}

\begin{abstract}
ABSTRAK
Penyakit kardiovaskular akibat aterosklerosis dinding pembuluh darah merupakan penyebab utama kematian di dunia yang dapat timbul karena kondisi hiperlipidemia. Minyak biji jintan hitam dan minyak zaitun diketahui dapat digunakan dalam terapi hiperlipidemia karena mengandung thymoquinone dan asam lemak tak jenuh tunggal yang tinggi. Salah satu bentuk sediaan yang dapat meningkatkan absorbsi dalam saluran cerna adalah mikroemulsi. Penelitian ini bertujuan untuk mendapatkan formulasi sediaan mikroemulsi mengandung minyak biji jintan hitam dan minyak zaitun yang sesuai dengan persyaratan farmasetika. Mikroemulsi minyak biji jintan hitam dan minyak zaitun $(3: 1)$ dibuat dengan variasi konsentrasi surfaktan cremophor RH 40, serta kosurfaktan gliserin dan PEG 400. Pada sediaan akhir ditambahkan pengawet Na-benzoat, antioksidan tokoferol, pemanis Nasakarin, dan perasa mentol. Sediaan akhir dievaluasi dengan pengamatan organoleptis, persen transmitan, $\mathrm{pH}$, viskositas, sifat alir, dan ukuran globul. Selain itu dilakukan uji stabilitas termodinamika dan uji stabilitas dipercepat pada suhu $25^{\circ} \mathrm{C}$ dan suhu $40^{\circ} \mathrm{C}$ selama penyimpanan 4 minggu. Formula mikroemulsi yang optimum dihasilkan dengan konsentrasi fasa minyak 5\%, cremophor RH 40 35\%, gliserin 35\% dan PEG 400 10\%. Sediaan akhir memiliki warna kuning-coklat, bau khas, rasa manis, bentuk yang jernih dan satu fasa, persen transmitan 100,367 $\pm 1,266, \mathrm{pH} 6,721 \pm 0,027$, viskositas $2306 \pm 206,64 \mathrm{cps}$, sifat alir newton dan ukuran globul $0,267 \mu \mathrm{m}$. Sediaan mikroemulsi stabil berdasarkan uji stabilitas termodinamika dan uji stabilitas dipercepat pada pengukuran $\mathrm{pH}\left(\mathrm{suhu} 25^{\circ} \mathrm{C}\right)$ dan viskositas ( $>>0,01)$.
\end{abstract}

Kata Kunci: Minyak biji jintan hitam, minyak zaitun, hiperlipidemia, mikroemulsi

\begin{abstract}
Cardiovascular disease caused by atherosclerosis of blood vessel walls is the leading cause of death in the world that can arise due to hyperlipidemic conditions. Black cumin seed oil and olive oil are known to be used in the treatment of hyperlipidemia because it contains thymoquinone and high monounsaturated fatty acids. One form of dosage forms that can increase absorption in the gastrointestinal tract is microemulsions. This study aimed to obtain the dosage form formulation of microemulsion contains black cumin seed oil and olive oil in accordance with pharmaceutical requirements. Microemulsion of black cumin seed oil and olive oil (3:1) made with variations in the concentration of surfactant Cremophor RH 40, cosurfactant glycerin and PEG 400. In the final dosage, it was with added Na-benzoate (preservative), tocopherol (antioxidant), Na-saccharin (sweeteners), and menthol (flavoring agent). The final dosage form was evaluated by organoleptic observation, transmittance percent, $\mathrm{pH}$, viscosity, flow properties, and globule size. In addition, thermodynamic stability tests and stability tests are accelerated at $250 \mathrm{C}$ and $400 \mathrm{C}$ for 4 weeks storage. Microemulsion optimum formula was developed by the concentration of oil phase $5 \%$, Cremophor RH 40 35\%, glycerin 35\% and 10\% PEG 400. Final dosage forms have yellowbrown color, typical smell, sweet taste, clear forms and single phase, transmittance percent
\end{abstract}


$100.367 \pm 1.266, \mathrm{pH} 6.721 \pm 0.027$, viscosity $206.64 \pm 2306 \mathrm{cps}$, Newtonian flow and globule size of $0.267 \mu \mathrm{m}$. Microemulsion dosage form was stable based on thermodynamic stability test and an accelerated stability test on $\mathrm{pH}$ measurement (temperature 250C) and viscosity $(\mathrm{p}>0.01)$.

Keywords: Black cumin seed oil, olive oil, hyperlidemia, microemulsion

\section{PENDAHULUAN}

Dislipidemia adalah kelainan metabolisme lipid yang ditandai dengan peningkatan maupun penurunan fraksi lipid dalam plasma. Kelainan fraksi lipid yang paling utama adalah kenaikan kadar kolesterol total, kolesterol LDL, kenaikan kadar trigliserida serta penurunan kadar HDL (Anwar, 2004). Dislipidemia adalah salah satu faktor resiko utama terjadinya aterosklerosis dinding pembuluh darah yang merupakan penyebab utama kematian di dunia. (Kemenkes RI, 2013; PERKI, 2013).

Minyak biji jintan hitam dan minyak zaitun merupakan dua bahan alam yang dapat digunakan dalam terapi dislipidemia, yaitu hiperlipidemia. Minyak biji jintan hitam terbukti menurunkan kadar kolesterol total dan kadar kolesterol LDL serta meningkatkan kadar kolesterol HDL karena mengandung thymoquinone (Al-Naqeep dkk, 2011). Manfaatnya pun terekam dalam sabda Rasulullah yaitu "Sesungguhnya di dalam habbatussaudah (jintan hitam) terdapat penyembuh bagi segala macam penyakit kecuali kematian”. (HR. Bukhari Muslim).

Minyak zaitun telah terbukti secara klinis memiliki efek terhadap penderita hiperlipidemia karena kandungan asam lemak tak jenuh tunggal serta berbagai kandungan fitokimia di dalamnya (Hasan dkk, 2013). Selain itu, buah zaitun disebutkan dalam firman Allah SWT, salah satunya dalam QS. Al-Mu'minun: 20-22.

Dan berdasarkan penelitian Mohammad (2013), kombinasi minyak biji jintan hitam dan minyak zaitun dengan konsentrasi $75 \%$ minyak biji jintan hitam dan 25\% minyak zaitun dapat menurunkan kadar kolesterol total dan trigliserida serta meningkatkan kadar protein total dengan hasil lebih baik dari bentuk tunggalnya. Sehingga dapat disimpulkan bahwa kombinasi minyak zaitun dan minyak biji jintan hitam menghasilkan efek yang sinergis.

Pada penelitian ini minyak biji jintan hitam dan minyak zaitun dikombinasikan menjadi fasa minyak dan dibuat menjadi sediaan oral dalam bentuk mikroemulsi untuk meningkatkan absorbsinya (Talegaonkar dkk, 2008). Mikroemulsi adalah sistem air, minyak dan surfaktan serta kosurfaktan yang transparan dan stabil secara termodinamika dengan ukuran tetesan berada di kisaran 0,1-

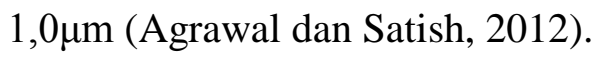

Tujuan dari penelitian ini adalah membuat sediaan mikroemulsi oral yang mengandung minyak biji jintan hitam dan minyak zaitun. Hasil dari penelitian ini diharapkan dapat memberikan informasi 
dalam dunia farmasi khususnya bagi para farmasis muslim dalam membuat new drug delivery system maupun dalam pemanfaatan bahan alam berdasarkan Al-Qur'an maupun hadits.

\section{METODE PENELITIAN}

\subsection{Alat}

Alat yang digunakan dalam penelitian ini adalah magnetic stirrer, $\mathrm{pH}$ meter (mettler toledo), timbangan analitik (mettler toledo), Brookfield KV-2 viscometer (ASTM D562 compatible), oven, kulkas, 80-2 centrifuge, tabung reaksi (pyrex), tabung sentrifuga (pyrex), gelas kimia (pyrex), pipet, batang pengaduk, spatula, spektrofotometri UV-Vis (Shimadzu), GC-MS (Gas Cromatography Mass Spectroscopy) dan Particle Size Analyzer (Beckman Coulter LS).

\subsection{Bahan}

Bahan yang digunakan dalam penelitian ini adalah minyak biji jintan hitam, minyak zaitun, cremophor RH 40, PEG 400, propilenglikol, gliserin, aquadest, tokoferol, natrium benzoat, mentol dan Na-sakarin.

\subsection{Metode}

Tahap awal penelitian adalah karakterisasi bahan baku untuk melihat kualitas dan mutu dari minyak dan dilakukan di BALITRO Kota Bogor. Selain itu digunakan GC-MS (Gas CromatographyMass Spectroscopy) untuk mengetahui kandungan senyawa dari minyak yang dilakukan di FPMIPA UPI.
Pada tahap awal formulasi dilakukan penentuan kelarutan minyak dalam masingmasing kosurfaktan terlebih dahulu untuk memilih kosurfaktan. Selanjutnya dilakukan optimasi formula mikroemulsi dengan variasi konsentrasi surfaktan dan kosurfaktan. Terhadap formula hasil optimasi dilakukan evaluasi organoleptis dan pengukuran \% transmitan. Setelah diperoleh formula paling optimum, dilakukan pembuatan sediaan akhir dengan penambahan natrium benzoat sebagai pengawet, tokoferol sebagai antioksidan serta perasa (Na-sakarin dan mentol).

Lalu dilakukan evaluasi sediaan meliputi uji organoleptik, persen transmitan, $\mathrm{pH}$, viskositas, dan stabilitas termodinamika serta karakterisasi sediaan mikroemulsi menggunakan instrumen particle size analyzer (PSA). Selain itu dilakukan juga uji stabilitas dipercepat selama 4 minggu pada suhu ruang $\left(25^{\circ} \mathrm{C}\right)$ dan suhu tinggi $\left(40^{\circ} \mathrm{C}\right)$ selama 28 hari kemudian dilakukan evaluasi pada minggu ke-0, 1, 2, 3, dan 4 .

\section{HASIL DAN PEMBAHASAN}

Pada awal penelitian dilakukan dilakukan karakterisasi minyak meliputi berat jenis, indeks bias, putaran optik, bilangan penyabunan, bilangan asam, bilangan iod, bilangan peroksida, dan kadar air untuk melihat kualitas serta mutu minyak yang digunakan. Hasil karakterisasi dapat dilihat pada Tabel 1. 
Tabel 1. Hasil Karakterisasi Minyak

\begin{tabular}{|c|c|c|}
\hline Parameter Karakterisasi & $\begin{array}{c}\text { Hasil karakterisasi } \\
\text { MBJH }\end{array}$ & $\begin{array}{c}\text { Hasil } \\
\text { karakterisasi MZ }\end{array}$ \\
\hline Berat jenis & 0,9183 & 0,9108 \\
\hline Indeks bias & 1,4721 & 1,4663 \\
\hline Putaran optik & Gelap/tidak terukur & $+0,30^{\circ}$ \\
\hline Bilangan penyabunan & 197,62 & 197,59 \\
\hline Bilangan asam & 15,69 & 1,36 \\
\hline Bilangan iod & 116,29 & 77,3 \\
\hline Bilangan peroksida & negatif & Negatif \\
\hline Kadar air & - & 0,25 \\
\hline
\end{tabular}

$\begin{array}{ll}\text { Keterangan : } & \\ \text { MBJH } & =\text { Minyak biji jintan hitam } \\ \text { MZ } & =\text { Minyak zaitun }\end{array}$

Berdasarkan hasil pengukuran

kombinasi minyak dengan perbandingan yang parameter karakterisasi minyak zaitun, terkecil dan menghasilkan tampilan fisik yang parameter bilangan penyabunan, bilangan paling jernih dipilih sebagai kosurfaktan asam, bilangan iod, dan bilangan peroksida diketahui memenuhi persyaratan minyak zaitun berdasarkan Standar Nasional Indonesia (SNI) untuk minyak zaitun. Namun hasil karakterisasi minyak biji jintan hitam belum dapat dibandingkan karena belum memiliki data standardisasi nasional (SNI).

Selain itu dilakukan juga identifikasi kandungan senyawa dengan menggunakan GC-MS. Hasil identifikasi kandungan senyawa dengan menggunakan GCMS menunjukkan bahwa benar terdapat asam lemak tak jenuh tunggal, khususnya asam oleat, pada minyak zaitun serta terdapat thymoquinone pada minyak biji jintan hitam. Kemudian dilakukan penentuan kosurfaktan yang akan digunakan dalam optimasi formula dengan cara menguji kelarutan minyak pada kosurfaktan. Kosurfaktan yang digunakan adalah PEG-400, propilenglikol, dan gliserin. Kosurfaktan yang dapat melarutkan untuk optimasi formula. Hasil uji kelarutan dapat dilihat pada Tabel 2.

Tabel 2. Hasil Uji Kelarutan

\begin{tabular}{|c|c|c|}
\hline $\mathrm{K}$ & $\mathrm{M}: \mathrm{K}$ & Kejernihan \\
\hline PEG-400 & $1: 1$ & ++ \\
\hline Gliserin & $1: 1$ & + \\
\hline Propilenglikol & $1: 1$ & - \\
\hline
\end{tabular}

$$
\begin{aligned}
& \text { Keterangan : } \\
& \mathrm{M}=\text { Minyak }++\quad=\text { Jernih } \\
& \mathrm{K}=\text { Kosurfaktan }+=\text { Kurang jernih } \\
& \text { Pada kebanyakan mikroemulsi }
\end{aligned}
$$

dibutuhkan kosurfaktan untuk membantu pembentukkan mikroemulsi dengan mengurangi tegangan permukaan (Talegaonkar dkk, 2008). Kosurfaktan yang terpilih adalah PEG 400, namun sediaan yang dibuat ditujukan untuk penggunaan oral sehingga penggunaah bahan yang tidak toksik pada saat pemakaian harus sangat diperhatikan, parameter yang dipertimbangkan adalah nilai ADI (Acceptable Daily Intake). Maka digunakan 
kombinasi kosurfaktan gliserin - PEG 400 dengan proporsi gliserin lebih banyak karena gliserin memiliki dosis maksimum harian yang lebih besar (Rowe dkk, 2009).

Kemudian dilakukan optimasi kosurfaktan untuk mendapatkan formula mikroemulsi yang stabil dengan \% $\mathrm{T}$ yang mendekati $100 \%$. Hasil optimasi dapat dilihat pada Tabel 3.

konsentrasi surfaktan dan kosurfaktan

Tabel 3. Hasil Optimasi Konsentrasi Surfaktan dan Kosurfaktan

\begin{tabular}{|c|c|c|c|c|c|c|c|}
\hline \multirow{2}{*}{ Bahan } & \multicolumn{7}{|c|}{ Konsentrasi (\%) } \\
\hline & F1 & F2 & $\mathbf{F 3}$ & F4 & F5 & F6 & F7 \\
\hline Minyak & 5 & 5 & 5 & 5 & 5 & 5 & 5 \\
\hline Cremophor RH 40 & 27,5 & 30 & 22,5 & 27,5 & 30 & 30 & 35 \\
\hline Gliserin & 27,5 & 30 & 22,5 & 27,5 & 30 & 35 & 35 \\
\hline PEG 400 & - & - & 10 & 10 & 10 & 10 & 10 \\
\hline Air ad. & 100 & 100 & 100 & 100 & 100 & 100 & 100 \\
\hline$\% \mathrm{~T}$ & 80,07 & 73,33 & 79,77 & 74,6 & 87,93 & 80,33 & 94,2 \\
\hline
\end{tabular}

Keterangan :

$\% \mathrm{~T}=$ persen transmitan

Minyak = minyak biji jintan hitam dan minyak zaitun (3:1)

Berdasarkan optimasi dan pengamatan yang dilakukan terhadap masing-masing formula, maka ditetapkan bahwa formula F7 yang dipilih karena penampilannya jernih secara organoleptis dan ditandai dengan $\% \mathrm{~T}$ nya yang paling mendekati $100 \%$ diantara formula yang lainnya.

Setelah didapatkan formula mikroemulsi yang paling optimal, maka dilakukan pembuatan sediaan akhir mikroemulsi dengan penambahan eksipien berupa pengawet (natrium benzoat), antioksidan (tokoferol), perasa (mentol) dan pemanis (Na-sakarin). Pengawet digunakan untuk mencegah terkontaminasinya sediaan oleh mikroorganisme. Antioksidan ditambahkan untuk mencegah terjadinya oksidasi pada sediaan yang akan mempengaruhi stabilitas sediaan. Selain itu ditambahkan pemanis berupa Na-sakarin dan perasa berupa mentol untuk menutupi rasa pahit pada sediaan sehingga nyaman untuk digunakan. Pada sediaan akhir mikroemulsi dilakukan evaluasi sediaan meliputi pengamatan organoleptis, persen transmitan, $\mathrm{pH}$, viskositas, sifat alir dan penentuan ukuran globul. Hasil dapat dilihat pada Tabel 4. Selain itu juga dilakukan uji stabilitas termodinamika dan uji stabilitas dipercepat.

Tabel 4. Hasil Evaluasi Sediaan Akhir

\begin{tabular}{|c|c|c|}
\hline Evaluasi & \multicolumn{2}{|c|}{ Hasil } \\
\hline \multirow{4}{*}{ Organoleptis } & Warna & Kuning-coklat \\
\hline & $\mathrm{Bau}$ & Khas \\
\hline & Rasa & Manis \\
\hline & Bentuk & Satu fasa, jernih \\
\hline$\% \mathrm{~T}$ & \multicolumn{2}{|c|}{$100,367 \pm 1,266$} \\
\hline $\mathrm{pH}$ & \multicolumn{2}{|c|}{$6,721 \pm 0,027$} \\
\hline Viskositas & \multicolumn{2}{|c|}{$2306 \pm 206,64$} \\
\hline Sifat alir & \multicolumn{2}{|c|}{ Newton } \\
\hline Ukuran globul & \multicolumn{2}{|c|}{$0,267 \mu \mathrm{m}$} \\
\hline
\end{tabular}


Pada pengamatan organoleptis, parameter yang diamati adalah warna, bau, rasa dan bentuk. Kemudian dilakukan evaluasi persen transmitan terhadap sediaan akhir. Persen transmitan (\% T) digunakan untuk mengukur kejernihan secara kuantitatif dari larutan atau sistem disperse. Nilai persen transmitan yang tinggi artinya ukuran globul semakin kecil (Abdassah, 2017). Persen transmitan yag dihasilkan telah memenuhi syarat karena menurut Rosano dan Clausse (1987) sistem mikroemulsi yang jernih yaitu mikroemulsi dengan transmitan sebesar $95 \%$. Begitu pun dengan pengukuran $\mathrm{pH}$ yang hasilnya sudah memenuhi rentang nilai $\mathrm{pH}$ yang diharapkan yaitu 4,5 - 7,5 (Maryam dan Balaji, 2015).

Selanjutnya evaluasi yang dilakukan terhadap sediaan akhir mikroemulsi yaitu uji viskositas dan sifat alir menggunakan viskometer Brookfield. Evaluasi ini dilakukan untuk mengetahui kemudahan dari sediaan untuk dituang. Berdasarkan hasil evaluasi, nilai viskositas yang dihasilkan dari tiap kecepatan spindel relatif stabil sehingga sediaan akhir mikroemulsi termasuk pada cairan Newton. Cairan newton adalah cairan yang tidak berubah viskositasnya pada berbagai kecepatan geser. Sehingga dapat diketahui bahwa sediaan akhir memiliki sifat alir Newtonian (Martin dkk, 2011).

Setelah itu dilakukan karakterisasi sediaan mikroemulsi dengan menggunakan PSA (Particle Size Analyzer) untuk mengetahui diameter globul rata-rata. Diameter globul rata-rata yang dihasilkan adalah $0,267 \mu \mathrm{m}$. Hal ini memenuhi syarat karena menurut Agrawal dan Satish (2012), ukuran globul mikroemulsi berada di kisaran antara $0,1-1,0 \mu \mathrm{m}$.

Setelah dilakukan evaluasi sediaan akhir, dilakukan uji stabilitas termodinamika dan stabilitas dipercepat. Uji stabilitas termodinamika dilakukan untuk melihat stabilitas fisik dari mikroemulsi, yang meliputi heating-cooling cycle, uji sentrifugasi, dan freeze-thaw cycle. Setelah pengujian semua sediaan tidak mengalami pemisahan fasa sehingga dinyatakan stabil. Emulsi konvensional dinyatakan tidak stabil secara termodinamika sedangkan mikroemulsi merupakan sistem yang stabil secara termodinamika (Fanun, 2011).

Sementara itu dilakukan juga pengujian stabilitas dipercepat dengan menyimpan sediaan di suhu ruang $\left(25^{\circ} \mathrm{C}\right)$ dan suhu tinggi $\left(40^{\circ} \mathrm{C}\right)$ selama 28 hari kemudian dilakukan evaluasi pengamatan organoleptis (bau, warna, rasa dan bentuk), pengukuran persen transmitan, pengukuran $\mathrm{pH}$, dan pengukuran viskositas pada minggu ke-0, 1, 2, 3, dan 4 .

Berdasarkan hasil pengujian statistika, semua evaluasi yang dilakukan selama pengujian stabilitas dipercepat menunjukkan hasil yang tidak berbeda secara signifikan selama masa penyimpanan. Kecuali pada evaluasi pengujian persen transmitan dan pengujian $\mathrm{pH} \quad\left(\right.$ suhu $\left.40^{\circ} \mathrm{C}\right)$, hal ini 
dikarenakan mikroemulsi yang distabilkan oleh surfaktan non-ionik sangat rentan terhadap suhu karena penurunan kelarutan surfaktan terjadi dengan meningkatnya suhu (Lawrence dan Rees, 2000). Namun nilai persen transmitan dan $\mathrm{pH}$ sediaan pada minggu ke-4 masih memenuhi persyaratan yaitu 95\% untuk persen transmitan dan 4,57,5 untuk pengukuran $\mathrm{pH}$ (Rosano dan Clausse, 1987; Maryam dan Balaji, 2015).

\section{KESIMPULAN}

Berdasarkan penelitian yang telah dilakukan, diketahui formula mikroemulsi yang paling baik adalah dengan jumlah fasa minyak 5\% (minyak biji jintan hitam dan minyak zaitun; 3:1), cremophor RH 40 35\%, gliserin 35\%, PEG 400 10\%, dan air 15\%. Sediaan memiliki nilai transmitan 100,367\%, $\mathrm{pH}$ 6,721, viskositas $2306 \mathrm{cps}$ dan ukuran globul 0,267 $\mu \mathrm{m}$. Sediaan tersebut stabil berdasarkan uji stabilitas termodinamika dan uji stabilitas dipercepat pada pengukuran $\mathrm{pH}$ (suhu $25^{\circ} \mathrm{C}$ ) dan viskositas dengan $p$-value > 0,01 .

\section{UCAPAN TERIMA KASIH}

Terimakasih kepada semua pihak yang telah membantu baik secara moril maupun materil sehingga penelitian ini dapat terselenggara.

\section{DAFTAR PUSTAKA}

Abdassah, Marline. (2017). Nanopartikel dengan Gelasi Ionik. Farmaka, 15 (1), 51.

Agrawal OP, Satish A. (2012). An Overview of New Drug Delivery System: Microemulsion. Asian Journal of
Pharmaceutical Science \& Technology, 2(1), 5.

Al-Naqeep G, Zubairi AS, Ismail M, Amom ZH, Esa NM. (2011). Antiatherogenic Potential of Nigella sativa Seeds and Oil in Diet-Induced Hypercholesterolemia in Rabbits. Evidence-Based Complementary and Alternative Medicine: 6.

Anwar, T. Bahri. (2004). Dislipidemia sebagai Faktor Resiko Penyakit Jantung Koroner. Fakultas Kedokteran Universitas Sumatera Utara, Medan, 2.

Fanun, Monzer. (2011). Colloids in Biotechnology. CRC Press, London, 383.

Hasan SN, Singh D, Siddiqul SS, Kulshreshtha M, Aggarwal T. (2013). Effects of Olive Oil on Lipid Profile in Hyperlipidaemic Patients. National Journal Of Medical Research., 3(4), 312.

Kemenkes RI. (2013). Riset Kesehatan Dasar 2013. Badan Penelitian dan Pengembangan Kesehatan Kementrian Kesehatan Republik Indonesia, Jakarta, 9.

Lawrence MJ, Rees GD. (2000). Microemulsion-based Media as Novel Drug Delivery Systems. Advanced Drug Delivery Reviews, 45, 94.

Martin AN, Sinko PJ. (2011). Martin's Physical Pharmacy and Pharmaceutical Sciences: Physical Chemical and Biopharmaceutical Principles in the Pharmaceutical Sciences. Lippincott Williams \& Wilkins, Philadelphia, 470.

Maryam T, Balaji. (2015). Formulation and In-Vitro Evaluation of Vincristine Microemulsion by using Nigella Sativa Oil. International Journal of Farmacia, 1(2), 81-83.

Mohammad, Ahmed Jasim. (2013). Role of Black Seed Oil (Nigella sativa) and Olive Oil Combination on Serum Rabbit Treated with Cholesterol. International Journal of Science and Research (IJSR)., 4, 658.

PERKI. (2013). Pedoman Tatalaksana Displipidemia Edisi Ke-1. Perhimpunan Dokter Spesialis Kardiovaskular Indonesia, Jakarta, 1.

Rowe, RC, Sheskey PJ, Owen SC (Eds). (2006). Handbook of Pharmaceutical 
Excipient, 6th ed. The Pharmaceutical Press, London, 521.

Rosano HL, Clausse M. (1985). Microemulsion System. Marcel Dekker Inc., New York and Basel, 269.

Talegaonkar S, Adnan A, Farhan JA, Roop KK, Shadab A, Pathan, Zeenat IK. (2008). Microemulsion: A Novel Approach to Enhanced Drug Delivery. Recent Patents on Drug Delivery \& Formulation, 2, 238240. 